\title{
THE IMPORTANCE OF THE CAIRO GENIZAH FOR THE HISTORY OF MEDICINE
}

\author{
by \\ P. FENTON*
}

AMONG THE hoard of manuscripts that found their way at the end of the last century from the depository ("genizah") of an ancient Cairo Synagogue to different libraries of the West, many hundreds of medical writings are to be found. The largest collection of these manuscripts, which range from tiny fragments to complete works, is preserved in the Cambridge University Library. The majority of these, written on parchment or paper, date from the twelfth century and, although of considerable interest for the history of medicine, have received relatively little attention.

Most of the medical fragments have been grouped in boxes K 14, Arabic 11, Arabic 38-45, NS 90, 222 and AS 144 of the Taylor-Schechter Genizah Collection, although many more are to be found dispersed throughout the entire collection. A large proportion of the texts are written in Judaeo-Arabic, that is Arabic written in Hebrew characters for the use of Jewish readers, although texts, some of which are illuminated, in Arabic, Hebrew, and even Judaeo-Spanish, also abound. The multifarious contents of these manuscripts testify to the great interest which the Jews of the Middle Ages cultivated in medicine. This is in fact only to be expected since in the Muslim countries of the Near East, Jews were often employed as physicians, some attaining to positions of high eminence. 1

The items most frequently found in the collection are the Arabic and Hebrew translations of Greek medical writings, the most outstanding of which are Hippocrates and Galen, as well as the classical works of the Arabs, such as Ali at-Tabari's Garden of wisdom, Avicenna's Quanun, and treatises of Averroes and Rhazes. Besides these, scores of medical treatises by little-known authors have been preserved, ranging from dissertations on anatomy to treatises on optics, including the earliest medical works written in Hebrew.

In addition there is a host of secondary material with a range of interest unequalled by any other collection of medical writings. It includes medical responsa, technical and herbal dictionaries in diverse languages, pharmacopoeias, popular recipes, and detailed prescriptions.

The importance of all the above-mentioned manuscripts for the establishment of scientific editions cannot be overstressed for in many cases they represent very early versions of important texts, some of which are even autographs. ${ }^{2}$ On the other hand some of the manuscripts constitute the only surviving versions of medical works. Consequently they are of prime importance for the history of medieval medicine.

* Dr. P. Fenton, Taylor-Schechter Genizah Research Unit, Cambridge University Library, West Road, Cambridge.

1 See M. Meyerhof, 'Mediaeval Jewish physicians in the Near East', Isis, 1938, 28: 432-460; and M. Perlmann, 'Notes on the position of Jewish physicians in Mediterranean Muslim countries', Israel Oriental Studies, 1972, 2: 315-319.

2 E.g., T-S Misc. 34.24+Ar. 44.79, 4 leaves from Maimonides' Treatise on sexual matters, written in his own hand. 


\section{Short Articles}

Indeed many are the names of unknown authors or unknown works of celebrated authors that can be recovered in this way. Particularly interesting in this respect are the numerous tables of contents and colophons in the fragments. These furnish a mine of precious information concerning the actual contents of forgotten works, the exact titles of their authors, and even, in some cases, the dates of their composition.

Apart from the medical material outlined above, the Genizah contains a large number of documents relating to the medical profession. ${ }^{3}$ These texts, though not directly medical, nevertheless constitute, in an incidental manner, a unique source of information about the internal history of medicine. They include private correspondence where medical advice is sought, inventories of doctors' libraries, ${ }^{4}$ from which much is to be culled concerning the sources and extent of medical knowledge at a given period, as well as prescriptions accompanied by the prices of the chemicals involved, and bills for doctors' fees, which give an idea of the economic aspect of the profession. There are also notes which once belonged to physicians, oculists, phlebotomists, and pharmacists, and furnish details, amongst other things, of academic courses and professional techniques.

As these documents originate not only from Egypt but also from localities as far off as Spain and India, a most valuable picture is drawn of how medicine was practised in those times and places.

Before, however, the Genizah's invaluable mine of information can properly and fully be exploited and appreciated, many hours must be spent in conservation, examination, decipherment, identification, and collation. There is no telling what discoveries are in store for the assiduous scholar in this as yet unexplored domain.

\footnotetext{
${ }^{3}$ Their scope has been outlined by S. D. Goitein, 'The medical profession in the light of the Cairo Genizah documents', Hebrew Union College Annual, 1963, 34: 177-194. See also, S. D. Goitein, A Mediterranean society, Berkeley, Los Angeles, and London, University of California Press, 1971, vol. 2, pp. 240-272, 575585.

4 Some of these inventories have been studied. See W. Bacher, 'La bibliothèque d'un médecin juif', Revue des Etudes Juives, 1900, 40: 55-61 ; E. J. Worman, Jewish Quarterly Review, 1907-8, 20: 460-463; D. Baneth, 'A doctor's library in Egypt at the time of Maimonides', Tarbiz. A Quarterly for Jewish Studies, 1960, 30: 171-185 [in Hebrew].
} 